\title{
Pengaruh Pencucian, Pembungkusan dan Penyimpanan suhu rendah Terhadap Kualitas Telur Ayam Ras (Gallus L.)
}

\author{
Effect of Washing, Packaging, and Low Temperature Storaging on The Quality of Eggs \\ Muhammad Anwar Djaelani ${ }^{1 *}$, Zuni novika ${ }^{2}$, Nur Azizah ${ }^{2}$ \\ ${ }^{1}$ Departemen Biologi Fakultas Sains dan Matematika Universitas Diponegoro \\ ${ }^{2}$ Mahasiswa PS Biologi Departemen Biologi Fakultas Sains dan Matematika Universitas Diponegoro \\ *Email : muhammadanwardjaelani@rocketmail.com
}

Diterima 29 September 2018 / Disetujui 28 Januari 2019

\begin{abstract}
ABSTRAK
Telur merupakan salah satu sumber protein hewani bagi masyarakat Indonesia. Telur mengandung bahan organik yang mudah rusak. Salah satu faktor yang menyebabkan rusaknya telur adalah lama waktu penyimpanan. Kualitas telur perlu dipertahankan agar kandungan bahan kimia yang terdapat pada telur dapat dipertahankan kesegarannya. Penelitian ini bertujuan untuk menganalisis kualitas telur ayam setelah pencucian,pembungkusan dan penyimpanan. Variabel kualitas telur yang diamati meliputi nilai Haugh Unit, Indeks Kuning Telur, Nilai susut berat dan $\mathrm{pH}$ telur. Telur ayam yang digunakan sebanyak 60 butir dibagi menjadi 8 kelompok perlakuan. Kelompok I telur ayam tanpa dicuci disimpan pada suhu $31^{\circ} \mathrm{C}$, Kelompok II telur ayam tanpa dicuci dibungkus plastik wrap disimpan pada suhu $31^{\circ} \mathrm{C}$, Kelompok III telur ayam dicuci disimpan pada suhu $31^{\circ} \mathrm{C}$, Kelompok IV telur ayam dicuci dibungkus plastik wrap kemudian disimpan pada suhu $31^{\circ}$ C. Setiap kelompok perlakuan terdiri 5 ulangan. Penelitian ini menggunakan Rancangan acak lengkap dengan 4 kelompok perlakuan dan 3 kelompok waktu pengamatan. Pada hari ke 3 setelah telur dikeluarkan dari induk ayam dilakukan pencucian, pembungkusan telur dan penyimpanan. Pengamatan dilakukan pada hari 10, 17 dan 24. Data yang diperoleh dianalisis menggunakan ANOVA dengan taraf signifikansi 5\% dan uji lanjut BNT. Hasil penelitian menunjukkan pencucian mempercepat penurunan kualitas telur, pembungkusan dapat mempertahankan kualitas telur. Semua variabel penelitian menunjukkan penurunan seiring dengan bertambahnya waktu penyimpanan
\end{abstract}

Kata kunci: haugh unit, indek kuning telur, susut berat

\begin{abstract}
Eggs are one source of animal protein for the people of Indonesia. Eggs contain peris hable organic matter. One of the factors that cause egg damage is the length of storage time. Egg quality needs to be maintained so that the chemical contained in eggs can be maintained freshness. This study aims to analyze the quality of chicken eggs after washing, wrapping and storage. The observed egg quality variables were Haugh Unit value, Egg yolk index, weight loss value and egg pH. 60 chicken eggs were used, divided into 8 treatment groups. Group I without washing chicken eggs stored at temperature $31^{\circ} \mathrm{C}$, Group II chicken eggs without washing, wrapped in plastic wrap stored at temperature $31^{\circ} \mathrm{C}$, Group III washed chicken eggs stored at $31^{\circ} \mathrm{C}$, Group IV washed, chicken eggs wrapped in plastic wrap then stored at temperature $31^{\circ} \mathrm{C}$. Each treatment group consisted of 5 replications. This study used a complete randomized design with 4 treatment groups and 3 groups of observation time. On the 3rd day after the egg is removed from the hen was washed, wrapping and storage. Observations were performed on days 10, 17 and 24. The data obtained were analyzed using ANOVA with significance level of 5\% and BNT advanced test. The results showed that washing accelerated the decline of egg quality, the wrapping can maintain egg quality. All research variables show decrease with increasing storage time
\end{abstract}

Keywords : haugh unit, egg yolk index, weight loss 


\section{PENDAHULUAN}

Telur merupakan makanan sumber protein hewani yang murah dan mudah untuk didapatkan oleh masyarakat Indonesia. Telur memiliki kandungan gizi yang lengkap mulai dari protein, lemak, vitamin, dan mineral. Kandungan asam amino essensial yang lengkap menjadikan telur sebagai patokan dalam menentukan mutu protein berbagai bahan pangan (Indrawan dkk., 2012). Telur mudah mengalami penurunan kualitas yang disebabkan oleh kerusakan secara fisik, serta penguapan air , karbondioksida, ammonia, nitrogen, dan hidrogen sulfida dari dalam telur (Muchtadi dkk., 2010). Lama penyimpanan menentukan kualitas telur, semakin lama telur disimpan, kualitas dan kesegaran telur semakin menurun (Haryoto, 2010). Telur ayam jika dibiarkan dalam udara terbuka (suhu ruang) telur hanya tahan 10-14 hari, setelah waktu tersebut telur mengalami perubahan-perubahan ke arah kerusakan seperti terjadinya penguapan kadar air melalui pori kulit telur yang berakibat kurangnya berat telur, perubahan komposisi kimia dan terjadinya pengenceran isi telur (Cornelia dkk., 2014). Lama penyimpanan juga berpengaruh sangat nyata terhadap kualitas telur, semakin lama telur disimpan, kualitas dan kesegaran telur semakin menurun. Kualitas tersebut ditinjau dari Haugh Unit telur dan Indeks Kuning Telurnya (Haryoto, 2010). IKT merupakan suatu metode untuk mengetahui kondisi dalam telur secara umum dalam bentuk perhitungan yang terukur. Kerusakan tersebut disebabkan karena perubahan kandungan $\mathrm{CO} 2$ dalam albumen menyebabkan kerusakan pada telur yang mengakibatkan perubahan $\mathrm{pH}$ albumin menjadi basa (Hardini, 2000).

Berbagai cara dilakukan untuk mengurangi penurunan kualitas telur. Hal tersebut dilakukan dengan mencegah kontaminasi isi telur melalui cara menutup pori-pori kerabang telur dengan larutan kapur, parafin, minyak nabati, natrium silikat $\left(\mathrm{Na}_{2} \mathrm{SiO}_{4}\right)$, agar-agar, getah karet, sabun, gelatin, bahkan getah kaktus (Koswara, 2009). Putri (2016) menggunakan pasta rimpang temulawak untuk membungkus telur untuk mengurangi penurunan kualitas telur akibat lama waktu penyimpanan.

Kualitas telur dapat diamati dengan cara melakukan pengukuran terhadap Indeks Kuning Telur (IKT), Indeks Putih Telur (IPT), Haugh Unit (HU) susut bobot telur, serta ukuran rongga udara sebagai variabel dasar tolok ukur kualitas telur. pH (Fibrianti, 2012; Jazil dkk.,2013; Purwaningsih dkk.; 2016)

\section{METODE PENELITIAN}

Penelitian ini dilakukan di Laboratorium Biologi Struktur dan Fungsi Hewan Jurusan Biologi Fakultas Sains dan Matematika Universitas Diponegoro Semarang. Metode eksperimental dengan rancangan acak lengkap (RAL) (Hanafiah, 2001). Sampel yang digunakan pada penelitian ini adalah Telur ayam ras 60 butir, yang berasal dari peternakan di Boyolali Jawa Tengah telur. Kelompok I telur ayam tanpa dicuci, Kelompok II telur ayam tanpa dicuci dibungkus plastik wrap, Kelompok III telur ayam dicuci, Kelompok IV telur ayam dicuci dibungkus plastik wrap. Setiap kelompok perlakuan disimpan pada suhu $31^{\circ} \mathrm{C}$ dan terdiri dari 5 ulangan. Penelitian ini menggunakan Rancangan acak lengkap dengan 4 kelompok perlakuan dan 3 kelompok waktu pengamatan. Pada hari ke 3 setelah telur dikeluarkan dari induk ayam dilakukan pencucian. Pencucian Telur dilakukan dengan cara telur yang sudah diambil dibersihkan dengan cara dicuci menggunakan air mengalir. Pembungkusan telur dilakukan dengan plastik wrap. Kemudian telur disimpanan pada suhu ruang ( suhu $31^{\circ} \mathrm{C}$ ). Pengamatan dilakukan pada hari ke-10, hari ke-17 dan hari ke-24.Variabel kualitas telur yang diamati meliputi nilai Haugh Unit, Indeks Kuning Telur, Nilai susut berat dan $\mathrm{pH}$ telur.

Data hasil penelitian diuji normalitasnya dengan menggunakan uji Kolmogorov-Smirnov, dan dilanjutkan dengan uji homogenitas. hasil uji normalitas menunjukkan semua data terdistribusi normal dan homogen maka dilakukan uji statistik dengan menggunakan analisis parametrik dengan menggunakan ANOVA kemudian dilanjutkan dengan uji Duncan ( Santosa, 1999). 


\section{HASIL DAN PEMBAHASAN}

Data hasil penelitian selama periode penelitian menunjukkan nilai Haugh Unit menurun seiring lamanya waktu penyimpanan. Nilai Haugh Unit antar waktu pengamatan menunjukkan perbedaan yang nyata $(\mathrm{P}<0,05)$. Hal ini kemungkinan disebabkan lamawaktu penyimpanan yang berakibat putih telur menjadi encer. Menurut Koswara (2009) telur segar memiliki nilai Haugh Unit rata rata minimal 72 . Telur yang telah disimpan selama 1 minggu memiliki nilai Haugh Unit 41 yang termasuk dalam kualitas B. Penurunan nilai Haugh Unit terjadi akibat adanya penguapan air dan gas seperti $\mathrm{CO} 2$ yang menyebabkan putih telur kental menjadi semakin encer. Menurut USDA (2000) nilai Haugh Unit (HU) kurang dari 31 digolongkan kualitas $\mathrm{C}$, nilai Haugh Unit (HU) antara 31-60 digolongkan kualitas B, dan nilai Haugh Unit (HU) lebih dari 72 digolongkan kualitas AA.Semakin lama disimpan maka putih telur akan semakin encer. Penelitian Akyurek and Okur (2009) menunjukkan lama penyimpanan berakibat kenaikan putih telur dan kuning telur. Menurut Cornelia dkk. (2014) hal ini disebabkan terjadi penguapan air selama penyimpanan, terutama pada bagian putih telur dan sebagian kecil oleh penguapan gas-gas seperti $\mathrm{CO} 2, \mathrm{NH} 3, \mathrm{~N} 2$ dan $\mathrm{H} 2$ akibat degradasi komponen organik telur. Pada puth telur kadar airnya berkurang karena mengalami evaporasi, berkurangnya kemampuan mengikat protein, kadar fosfor bertambah sehingga puth telur menjadi encer sehingga menurunkan nilai HU. Menurut Nugroho dan Manyun (2008), yang menyatakan bahwa pengenceran bagian puth telur disebabkan oleh adanya kerusakan fisikokimia dari serabut ovomucin. Ovomucin merupakan glikoprotein yang berbentuk serabut atau jala-jala yang dapat mengikat cairan telur untuk dibentuk menjadi struktur gel pada putih telur.

Tabel 1. Hasil Pengukuran Haugh Unit dan IKT selama periode penelitian

\begin{tabular}{cccccc}
\hline $\begin{array}{c}\text { Kelompok } \\
\text { perlakuan }\end{array}$ & $\begin{array}{c}\text { Hari } \\
\text { Pengamatan }\end{array}$ & Haugh Unit & $\begin{array}{c}\text { Indeks Kuning } \\
\text { Telur }\end{array}$ & $\begin{array}{c}\text { Susut Berat } \\
\text { Telur }\end{array}$ & pH Telur \\
\hline Kelompok I & 10 & $66,3 \pm 1,9^{\mathrm{b}}$ & $0,38 \pm 0,008^{\mathrm{h}}$ & $2,41 \pm 0,17^{\mathrm{n}}$ & $7,88 \pm 0,05^{\mathrm{v}}$ \\
Kelompok I & 17 & $57,4 \pm 2,7^{\mathrm{c}}$ & $0,35 \pm 0,004^{\mathrm{i}}$ & $3,06 \pm 0,8^{\circ}$ & $8,30 \pm 0,07^{\mathrm{w}}$ \\
Kelompok I & 24 & $48,6 \pm 3,1^{\mathrm{d}}$ & $0,32 \pm 0,006^{\mathrm{j}}$ & $3,36 \pm 0,10$ & $8,54 \pm 0,04^{\mathrm{x}}$ \\
Kelompok II & 10 & $75,3 \pm 2,3^{\mathrm{a}}$ & $0,42 \pm 0,013^{\mathrm{g}}$ & $1,85 \pm 0,27^{\mathrm{m}}$ & $7,65 \pm 0,06^{\mathrm{u}}$ \\
Kelompok II & 17 & $69,6 \pm 2,2^{\mathrm{b}}$ & $0,39 \pm 0,007^{\mathrm{h}}$ & $2,25 \pm 0,17^{\mathrm{n}}$ & $7,77 \pm 0,6^{\mathrm{v}}$ \\
Kelompok III & 24 & $59,6 \pm 3,3^{\mathrm{c}}$ & $0,36 \pm 0,003^{\mathrm{i}}$ & $2,88 \pm 0,12^{\circ}$ & $8,15 \pm 0,08^{\mathrm{w}}$ \\
Kelompok III & 10 & $45,1 \pm 2,1^{\mathrm{d}}$ & $0,30 \pm 0,008^{\mathrm{j}}$ & $3,56 \pm 0,06^{\mathrm{p}}$ & $8,76 \pm 0,06^{\mathrm{x}}$ \\
Kelompok III & 17 & $29,5 \pm 1,3^{\mathrm{e}}$ & $0,25 \pm 0,015^{\mathrm{k}}$ & $3,73 \pm 0,11^{\mathrm{q}}$ & $9,10 \pm 0,09^{\mathrm{y}}$ \\
Kelompok III & 24 & $26,3 \pm 1,2^{\mathrm{f}}$ & $0,22 \pm 0,011^{1}$ & $3,98 \pm 0,11^{\mathrm{r}}$ & $9,50 \pm 0,10^{\mathrm{z}}$ \\
Kelompok IV & 10 & $65,3 \pm 1,7^{\mathrm{b}}$ & $0,37 \pm 0,005^{\mathrm{h}}$ & $2,56 \pm 0,18^{\mathrm{n}}$ & $8,00 \pm 0,7^{\mathrm{v}}$ \\
Kelompok IV & 17 & $56,2 \pm 1,8^{\mathrm{c}}$ & $0,34 \pm 0,004^{\mathrm{i}}$ & $3,21 \pm 0,07^{\mathrm{o}}$ & 32 \\
\hline Kelompok IV & 24 & $46,1 \pm 2,1^{\mathrm{d}}$ & $0,31 \pm 0,004^{\mathrm{j}}$ & $3,46 \pm 0,06^{\mathrm{p}}$ & $8,43 \pm 0,5^{\mathrm{w}}$ \\
\hline
\end{tabular}

Keterangan: angka yang diikuti superskrip yang berbeda pada kolom yang sama menunjukan hasil yang berbeda nyata $(\mathrm{P}<0,05)$. Kelompok I telur ayam tanpa dicuci, Kelompok II telur ayam tanpa dicuci dibungkus plastik wrap, Kelompok III telur ayam dicuci, Kelompok IV telur ayam dicuci dibungkus plastik 
Hasil analisis data menunjukkan indeks kuning telur antar waktu pengamatan berbeda nyata $(\mathrm{P}<0,05)$. Hal ini kemungkinan disebabkan encerny putih telur akibat lama waktu penyimpanan berakibat air mengalir dari putih telur ke kuning telur. Masuknya air dari puti telur ke kuning telur mengakibatkan rusaknya kuning telur. Menurut Koswara (2009), semakin tua umur telur sejak telur dikeluarkan dari induk unggas Indeks Kuning telur menurun karena penambahan ukuran kuning telur akibat perpindahan air dari putih ke kuning telur. Hal ini sesuai dengan pernyataan Djaelani (2015) menyatakan bahwa semakin lama penyimpanan menyebabkan menyebabkan putih telur kental menjadi semakin encer. Penelitian Akyurek and Okur (2009) menunjukkan lama penyimpanan berakibat kenaikan putih telur dan kuning telur. Akibat dari kenaikan $\mathrm{pH}$ putih telur menjadi semakin encer. Menurut Hardini (2000), pada awal penyimpanan telur. Indeks kuning telur akan cepat mengalami penurunan karena terjadinya penguapan air dan gas $\mathrm{CO} 2$ berlangsung lebih cepat karena jumlah cairan lebih banyak, semakin meningkatnya umur penyimpanan menyebabkan persediaan cairan dan gas akan semakin berkurang. Sudaryani (2003), juga menyatakan bahwa telur akan mengalami perubahan kualitas seiring dengan lamanya penyimpanan. Semakin lama penyimpanan indeks kuning telur semakin menurun, hal ini disebabkan karena membran vitelin pada kuning telur dan sebagian protein-proteinnya telah rusak. Hal tersebut berakibat membran vitelin menjadi lebih elastis sehingga mengakibatkan aliran air terus menerus dari bagian putih telur ke bagian kuning telur.

Hasil analisis data $\mathrm{pH}$ telur ayam menunjukkan antar kelompok waktu penyimpanan menunjukan hasil yang berbeda nyata $(\mathrm{P}<0,05)$. Hajrawat dan Answar (2011) menyatakan bahwa $\mathrm{pH}$ akan naik karena telur kehilangan $\mathrm{CO}_{2}$. Kadar air pada telur akan hilang akibat lama penyimpanan yang mempercepat terjadinya reaksi metabolisme. Telur yang baru dikeluarkan $\mathrm{pH}$ nya berkisar 7,6-7,93 dan meningkat sampai nilai maksimal 9,7. Peningkatan $\mathrm{pH}$ menjadi basa karena disebabkan oleh lepasnya $\mathrm{O}_{2}$ melalui pori cangkang (Rizal dkk., 2012). Perubahan kandungan $\mathrm{CO}_{2}$ dalam putih telur akan mengkibatkan perubahan $\mathrm{pH}$ putih telur menjadi basa (Cornelia, 2014). Selama penyimpanan $\mathrm{pH}$ telur menjadi semakin meningkat dari telur segar dengan $\mathrm{pH}$ 8. $\mathrm{pH}$ telur meningkat menjadi 9 setelah 1 minggu waktu penyimpanan dan telur meningkat menjadi 9,5 setelah 2 minggu waktu penyimpanan. Jazil (2013), menyatakan bahwa $\mathrm{CO}_{2}$ yang hilang melalui pori kerabang telur mengakibatkan konsentrasi ion bikarbonat dalam putih telur menurun dan merusak sistem buffer. Hal tersebut menjadikan $\mathrm{pH}$ naik dan putih telur bersifat basa yang diikuti dengan kerusakan serabut serabut ovomucin yang memberikan tekstur kental, sehingga kekentalan putih telur menurun.

Hasil analisis data menunjukkan nilai susut berat telur ayam ras berbeda selama penyimpanan. Lama penyimpanan yang berbeda berpengaruh nyata terhadap susut berat telur. Semakin lama waktu penyimpanan semakin bertambah besar penyusutan berat telur. Menurut Jazil dkk.,(2013) penyusutan berat telur yang terjadi selama penyimpanan disebabkan oleh penguapan air dan pelepasan gas $\mathrm{Cn} 2$ dari dalam isi telur melalui pori kerabang. Penguapan dan pelepasan gas ini terjadi secara terus menerus selama penyimpanan sehingga semakin lama telur disimpan berat telur akan semakin berkurang. Rata rata penyusutan berat telur setiap minggunya adalah 2,60 g. Menurut Sudaryani (2000) penguapan air dan pelepasan gas seperti $\mathrm{CO}_{2}, \mathrm{NH}_{3}, \mathrm{~N}_{2}$, dan sedikit $\mathrm{H}_{2} \mathrm{~S}$ sebagai hasil degradasi bahan bahan organik telur terjadi sejak telur keluar dari tubuh ayam melalui pori kerabang telur dan berlangsung secara terus menerus sehingga menyebabkan penurunan kualitas puth telur, terbentuknya rongga udara, dan menurunkan berat telur. Rata rata penyusutan berat telur pada minggu pertama dan kedua adalah sebesar 1,47 $\mathrm{g}$ dan $2,77 \mathrm{~g}$ yang berarti terjadi penurunan berat rata rata tiap minggunya adalah 2,2 g.

Menurut Yuwanta (2010) yang menyatakan bahwa pada suhu penyimpanan $25^{\circ} \mathrm{C}$ dengan kelembaban relatif $70 \%$ akan menyebabkan telur kehilangan berat berkisar sekitar 0,8 gram setiap minggu setiap butirnya dan pada suhu $30^{\circ} \mathrm{C}$ telur akan kehilangan berat 
sebesar berkisar 2 gram setiap minggu setiap butirnya Apabila kelembaban udara ruang penyimpanan relatif meningkat menjadi $80 \%$, maka penurunan berat air dalam telur bertambah sebesar $20 \mathrm{mg} /$ hari/butir pada berat telur 60 gram.

Menurut Fibrianti dkk.,(2012), pencucian menyebabkan pori kerabang telur terbuka, hal tersebut disebabkan hilangnya selaput kutikula yang melapisi telur hilang karena pencucian. Perlakuan pencucian menyebabkan kutikula pada telur hilang sehingga permukaan kerabang telur halus dan mengalami keretakan (Park et al., 2003),. Hilangnya selaput kutikula menyebabkan penguapan bertambah cepat, sehingga memungkinkan telur yang dicuci dan disimpan akan menurun kualitasnya. Hasil penelitian menunjukkan kelompok telur yang dilakukan pencucian sebelum dilakukan penyimpanan nilai Haugh unit, nilai indeks kuning telur $\mathrm{pH}$ telur, dan susut berat telur lebih rendah dibanding kelompok telur tanpa pencucian.

Pembungkusan telur memiliki pengaruh pada kualitas telur khususnya putih telur. Telur tanpa pembungkusan berpengaruh terhadap suhu dan kelembaban lingkungan yang menyebabkan kenaikan penguapan air sehingga berakibat terjadinya penyusutan berat telur (Putri 2016). Pembungkusan telur saat disimpan menyebabkan penguapan berkurang, sehingga memungkinkan telur yang dibungkus dan disimpan akan bertahan kualitasnya. Hasil penelitian menunjukkan kelompok telur yang dilakukan pembungkusan sebelum dilakukan penyimpanan nilai Haugh unit, nilai indeks kuning telur, $\mathrm{pH}$ telur, dan susut berat telur lebih tiggi dibanding kelompok telur tanpa pembungkusan.

Selama penelitian suhu rata rata pada pagi hari adalah $28^{\circ} \mathrm{C}$ dengan kelembaban relatif $80 \%$, pada siang hari suhu rata rata ruangan sebesar $34^{\circ}$ C dengan kelembaban relatif $62 \%$ dan pada sore hari sebesar $29^{\circ} \mathrm{C}$ dengan kelembaban relatif $70 \%$ sedangkan rata rata suhu dan kelembaban relatif secara keseluruhan adalah $31^{\circ} \mathrm{C}$ dan $75 \%$. menurut BSN (2008) suhu ruang yang cukup tinggi mengakibatkan telur hanya mampu bertahan selama 14 hari setelah peneluran. penyimpanan telur konsumsi yang ideal adalah pada suhu $27^{\circ} \mathrm{C}$ dengan kelembaban relatif $60 \%$. Telur segar yang disimpan pada suhu kamar dengan kelembaban relatif berkisar $80 \%$ maksimum hanya mampu bertahan selama 14 hari penyimpanan.

\section{DAFTAR PUSTAKA}

Akyurek, H. and A.A. Okur. 2009. Effect of Storage Time, Temperature and Hen Age on Egg Quality in Free-Range Layer Hens. Journal of Animal and Veterinary Advances 8 (10): 1953-1958

Badan Standarisasi Nasional(BSN). 2008. SNI 3926:2008 Telur AyamKonsumsi. BSN, Jakarta.

Cornelia,A., I. K. Suada dan M. D. Rudyanto. Perbedaan Daya Simpan Telur Ayam Ras yang Dicelupkan dan Tanpa Dicelupkan Larutan Kulit Manggis Indonesia Medicus Veterinus 2014 3(2) : 112 - 119 ISSN : 2301-7848

Djaelani, A. M. 2015. Pengaruh Pencelupan pada Air Mendidih dan Air Kapur Sebelum Penyimpanan Terhadap Kualitas Telur Ayam Ras (Gallus L.). Buletin Anatomi dan Fisiologi Jurusan Biologi Fakultas Sains dan Matematika Universitas Diponegoro Semarang 23(1) :24-30.

Fibrianti,S.M., I. K. Suada dan M. D. Rudyanto. 2012. Kualitas Telur Ayam Konsumsi yang Dibersihkan dan Tanpa Dibersihkan Selama Penyimpanan Suhu Kamar. Indonesia Medicus Veterinus 2012 1(3) : 408 - 416 ISSN : 2301-7848

Hajrawat dan Aswar, M., 2011. Kualitas Interior Telur Ayam Ras Dengan Penggunaan Larutan Daun Sirih (Piper betle) Sebagai Bahan Pengawet. Seminar Nasional Teknologi Peternakan dan Veteriner. Makasar

Hanafiah, K.A. 2001. Rancangan Percobaan Teori dan Aplikasi. Raja Grafindo Persada, Jakarta.

Hardini. 2000. Pengaruh Suhu dan Lama Penyimpanan Telur Konsumsi dan Telur Biologis Terhadap Kualitas Interior Telur Ayam Kampung. FMIPA Universitas Terbuka 
Haryoto. 2010. Membuat Telur Asin. Kanisius. Yogyakarta.

Indrawan, I.G., Sukada, I.M., \& Suada, I.K. 2012. Kualitas Telur dan Pengetahuan Masyarakat tentang Penanganan Telur di Tingkat Rumah Tangga. Artikel Telur. ISSN: 2301-784

Jazil,N., A. Hintono dan S. Mulyani (2013) Penurunan Kualitas Telur Ayam Ras dengan Intensitas Warna coklat kerabang berbeda selama penyimpanan. Jurnal Aplikasi Teknologi Pangan Vol. 2 No. 1

Koswara, S. (2009) Teknologi Pengolahan Telur . eBookPangan.com

Nugroho dan Manyun, I.G.T. 2008. Beternak Burung Puyuh. Eka Offset. Semarang

Muchtadi, T. R, Putristaningwarno, $\mathrm{F}$ dan Sugiyono. 2010. Ilmu Pengetahuan Bahan Pangan. Penerbit Alfabeta. Bandung.

Park, Y.S., I.J. Yoo, K.H. Jeon, H.K. Kim, E.J. Chang and H.I. Oh. 2003. Effects of Various Eggshell Treatments on The Egg Quality during Storage. J. Anim. Sci, Korea.

Purwaningsih,D., M.A. Djaelani, dan T.R. Saraswatil 2016. Kualitas Telur Ayam Ras Setelah Pemberian Olesan Lidah
Buaya ( Aloe vera) dan Lama Penyimpanan Waktu yang Berbeda Buletin Anatomi dan Fisiologi Jurusan Biologi Fakultas Sains dan Matematika Universitas Diponegoro Semarang 24(1) : 13-20.

Putri,D.A.M., M.A. Djaelani,dan S.M. Mardiati. 2016 Bobot, Indeks Kuning Telur (IKT), Dan Haugh Unit (Hu) Telur Ayam Ras Setelah Perlakuan Dengan Pembungkusan Pasta Rimpang Temulawak (Curcuma Xanthorrhiza Roxb). Bioma Berkala Ilmiah Biologi 18(1) : 7-13.

Rizal. B, A. Hintono, dan Nurwantoro. 2012. Pertumbuhan mikroba pada telur pasca peusterisasi. Anim Agri J, 1 (2) : 208-218

Santoso, S. Panduan lengkap menguasai SPSS 16. 2008. Jakarta : PT Elex Media Komputindo, $237-248$.

Sudaryani, T. 2003. Kualitas Telur. Penebar Swadaya, Jakarta

United States Departement of Agriculture (USDA). 2000. gerading Manual Agricultural Handbook number 75, Washington DC.

Yuwanta, T. 2010. Telur dan Kualitas Telur. Gadjah Mada University Press, Yogyakarta. 